\title{
Definition of
}

Stage-Discharge Relation

in Natural Channels by

Step-Backwater Analysis

GEOLOGICAL SURVEY WATER-SUPPLY PAPER 1869-A

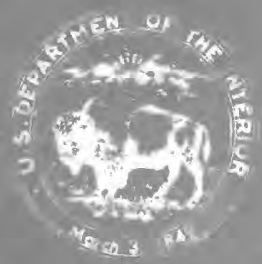




\section{Definition of}

\section{Stage-Discharge Relation}

in Natural Channels by

\section{Step-Backwater Analysis}

By J. F. BAILEY and H. A. RAY

RIVER HYDRAULICS

GEOLOGICAL SURVEY WATER-SUPPLY PAPER 1869-A

An evaluation of the accuracy of the step-backwater method of establishing stage-discharge relations

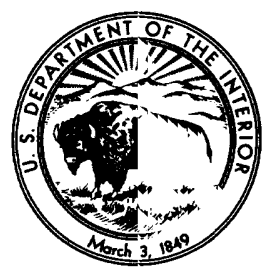


UNITED STATES DEPARTMENT OF THE INTERIOR

WILLIAM P. CLARK, Secretary

GEOLOGICAL SURVEY

Dallas L. Peck, Director

First printing 1966

Second printing 1982

Third printing 1984 604 South Pickett Street, Alexandria, VA 22304 


\section{CONTENTS}

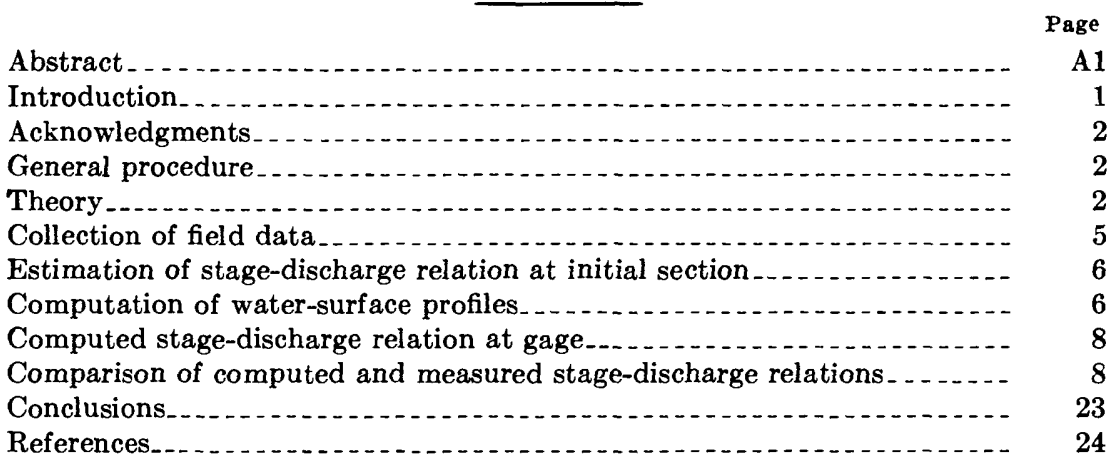

\section{ILLUSTRATIONS}

Figure 1. Sketch of normal, M1, and M2 profiles..............

2. Equations 2 and 3 for determination of distance required for convergence.

3. Water-surface profile convergence pattern, Big Knob Creek near Fallston, N.C

4-31. Rating curves for:

4. Austin Creek near Cazadero, Calif _........ 9

5. Big Knob Creek near Fallston, N.C.......... 9

6. Bluestone River near Pipestem, W. Va _..... 10

7. Cache Creek at Yolo, Calif _............. 10

8. Chattahoochee River near Leaf, Ga ......... 11

9. Deep River at Ramseur, N.C._._. . . . . . 11

10. Elk River below Webster Springs, W. Va . . . . . 12

11. Eno River at Hillsboro, N.C. . . . . . . 13

12. Etowah River near Dawsonville, Ga ......... 13

13. Haw River near Benaja, N.C............... 14

14. Kalihi Stream at Kalihi, Hawaii .............. 14

15. Mokelumne River near Mokelumne Hill, Calif _.. $\quad 15$

16. Monocacy River at Bridgeport, Md......... 15

17. Murder Creek near Monticello, Ga............. 16

18. Outlet Creek near Longvale, Calif............. 16

19. Russian River near Hopland, Calif _......... 17

20. Schuylkill River at Pottstown, $\mathrm{Pa} \ldots \ldots \ldots \ldots$

21. Second Brcad River at Cliffside, N.C.......... 18

22. South Beaverdam Creek at Dewy Rose, Ga.... 18

23. South Fork Tule River near Success, Calif _. . ... 19

24. South River near Waynesboro, Va _.......... 19

25. South Tyger River near Reidsville, S.C._._._. 19 
Figures 26-31. Rating curves-Continued Page

26. South Yadkin River near Mocksville, N.C _ . ... A20

27. Tanana River near Tanacross, Alaska . . . . . . . 20

28. Truckee River at Reno, Nev . . .

29. Umpqua River near Elkton, Oreg .......... 21

30. Willamina Creek near Willamina, Oreg ........ 22

31. Yellow River near Snellville, Ga ............... 22

32. Computed discharge compared with measured discharge.. 23

\section{TABLE}

TARLE 1. Summary of channel characteristics for step-backwater reaches-

\section{SYMBOLS}

A Area of a cross section, in square feet.

$\alpha \quad$ Velocity-head coefficient.

$B \quad$ Top width of a cross section, in feet.

$C \quad$ Coefficient in Chezy formula $V=C \sqrt{R S}$.

$d_{m} \quad$ Mean depth defined as $A / B$, in feet.

F Froude number, equal to $V / \sqrt{g d_{m}}$.

$g \quad$ Acceleration due to gravity, 32.2 feet per second per second.

$h \quad$ Water-surface elevation at a cross section, in feet.

$h_{d}, h_{u} \quad$ Water-surface elevation at the downstream and upstre?m ends of any reach, in feet.

$\Delta h$. Difference in velocity head between the upstream and downstream ends of the subreach, equivalent to $h_{v_{u}}-h_{v_{d}}$, in feet.

$h_{f} \quad$ Loss of head due to friction, defined as $L_{u d}\left[(1 / 2)\left(Q_{u}+Q_{d}\right)\right]^{2} / K_{u} K_{d}$, in feet.

$h$ Velocity head, equivalent to $\alpha V^{2} / 2 g$, in feet. Subscripts $d$ or $u$ apply to a downstream or upstream cross section.

$k \quad$ Energy-loss coefficient due to expansion of reach.

$k\left(\Delta h_{v}\right) \quad$ Energy loss due to expansion of reach and deceleration of flow, in fect.

$K \quad$ Total conveyance of a cross section, in cubic feet per second.

$K_{d}, K_{u}$ Conveyance at the downstream and upstream ends of any subreach, in cubic feet per second.

$L \quad$ Length required for convergence, in feet.

$L_{d u} \quad$ Length between downstream and upstream sections of a subreach, in feet.

$n \quad$ Manning roughness coefficient.

$Q \quad$ Discharge, in cubic feet per second.

$Q_{d}, Q_{u} \quad$ Discharge at the downstream and upstream ends of any reach, in cubic feet per second.

$R \quad$ Hydraulic radius of a section, equal to ratio of area to wetted perimeter, in feet.

$S_{0} \quad$ Bed slope of channel.

$V \quad$ Mean velocity at a cross section, equal to $Q / A$, in feet pel second.

$y \quad$ Arbitrarily selected depth at the initial section, in feet.

$y_{0} \quad$ Uniform flow depth, in feet. 


\title{
RIVER HYDRAULICS
}

\section{DEFINITION OF STAGE-DISCHARGE RELATION IN NATURAL CHANNELS BY STEP-BACKWATER ANALY'SIS}

\author{
By J. F. BAILEY and H. A. RAY
}

ABSTRACT

The step-backwater method was investigated as a technique for definins the upper part of stage-discharge relation in a natural channel. State-discharge relations at 28 sites were computed by using this technique and compared with corresponding stage-discharge relations defined by current-meter measurements. In general, the agreement is remarkably good, and the step-backwater method should prove useful at many sites where current-meter measurements ar? not obtained.

\section{INTRODUCTION}

Stage-discharge relations in natural channels are usually establi-hed by a series of current-meter measurements of discharge at various stages. During floods, however, it is frequently impossible or impractical to measure peak discharges when they occur becaus? of conditions beyond the hydrologist's control. Roads may be impassable, knowledge of the flood rise may not be available sufficiently in advance to permit the hydrologist to reach the site near the time of the peak, the flow of debris or ice may prevent the use of a current meter, or insufficient personnel may make it impossible to ot tain measurements at many locations during a short flood period. Consequently, the stage-discharge relation for floodflow must usually be determined by indirect methods.

Indirectly, discharge is measured by methods such as slope-area, contracted-opening, flow over dam, flow through culvert, and critical depth. These methods which are described in Techniques of Water Resources Investigations of the United States Geological Survey, book 3, chapters 3-7 (see under authors' names in list of references), utilize information on the water-surface profile for a specific flood peak and the hydraulic characteristics of the channel to determine the peak discharge. These methods have been used extensively for many years in the Geological Survey.

Anderson and Anderson (written commun., 1966) proposed a new indirect method of establishing stage-discharge relations in the range of stage for which current-meter measurements are not available and for which channel control is dominant. The proposed method uses 
the well established step-backwater method of computing watersurface profiles for given discharges.

The purpose of this investigation was to determine the reliability of the step-backwater method of establishing stage-discherge relations. Stage-discharge relations established for 28 stream gaging stations by the step-backwater method are compared with stige-discharge relations defined by current-meter measurements. The 28 stations are located throughout the United States and represent a variety of hydraulic conditions.

\section{ACKNOWLEDGMENTS}

This investigation was conducted under the general supervision of R. W. Carter, chief, Hydraulics Section, Surface Water Branch, Washington, D.C., and Walter Hofmann, district engineer, Surface Water Branch, Menlo Park, Calif.

The authors were aided in the field operations by personnel of the district offices in the States where the gaging stations are located.

\section{GENERAL PROCEDURE}

The general procedure for establishing a stage-discharge relation by the step-backwater method includes a transit-stacia survey of a long reach downstream from the gage, an estimate of a stagedischarge relation at the downstream end of the reach, and a computation of water-surface profiles in the reach for selected discharges. The end result of this procedure is a computed water-surface elevation at the gage corresponding to each selected discharge.

\section{THEORY}

The basic equation for computation of water-surface profiles from section to section in a reach of open channel is

$$
h_{d}+h_{v_{d}}+h_{f}+k\left(\Delta h_{v}\right)=h_{u}+h_{v_{u}} \text {, }
$$

where the subscripts $d$ and $u$ refer to the downstream $\varepsilon$.nd upstream cross sections, respectively, and where

$$
\begin{aligned}
h & =\text { water-surface elevation at a cross section, ir feet, } \\
h_{0} & =\frac{\alpha V^{2}}{2 g}=\text { velocity head at a cross section, in feet, }
\end{aligned}
$$


$K=\frac{1.486 A R^{2 / 3}}{n}$, total conveyance at a cross section, in cubic feet per second,

$k\left(\Delta h_{v}\right)=$ energy loss due to expansion of reach and deceleration of flow, in feet,

$k=$ one-half for expanding reaches and zero for contracting reaches.

The step-backwater method consists of solving the basic equation by trial and error computations within specified tolerances. This method is one of several used in the computation of gradually varied flow profiles. The method is applicable to subcritical or supercritical flow provided that subcritical flow computations are carried upstream and supercritical flow computations are carried downstream. The theory underlying the basic equation assumes that uniform-flow formulas are applicable to gradually varied flow conditions. The following ccnditions are assumed to be in effect:

1. Flow is steady.

2. Slope is small so that normal depths can be considered equal to vertical depths.

3. Water-surface elevation is level across a section.

4. Effects of sediment and air entrainment are negligible.

5. All energy losses are accounted for.

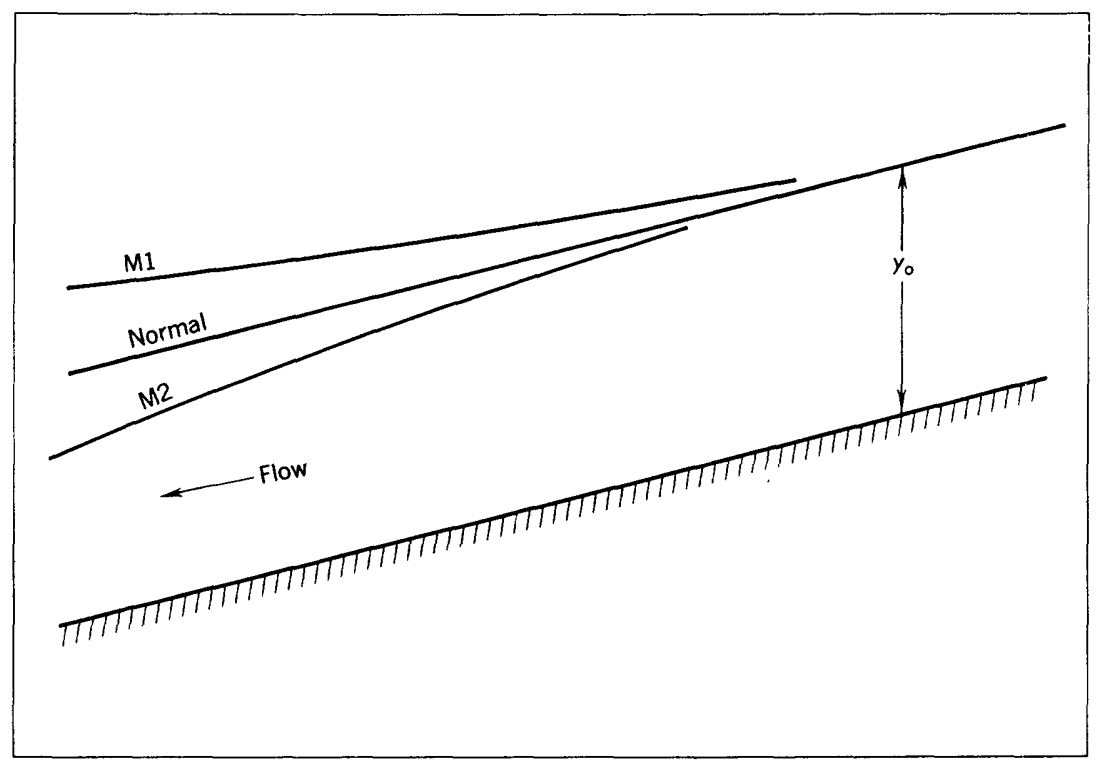

Figure 1.- Normal, M1, and M2 profiles. 
The step-backwater method is generally regurded as the best method for computation of flow profiles in natural channels. This method has two principal advantages: the maximum possible use of channel geometry is permitted, and several water-surface profiles of the same discharge starting with different water-surface elevations at the initial section will tend to converge to a single profile if backwater computations are carried upstream through an adequate reach length. Where these profiles converge, the computed elevation will be theoretically correct.

The convergence of water-surface profiles computed for the same subcritical discharge is illustrated in figure 1. If flow is uniform, the true profile will be parallel to the bed slope, and depth will be normal at all points in the reach. If the initial starting elevation for computations is estimated too high, the profile marked M1 will be computed; if the initial starting elevation is estimated too low, the profile marked M2 will be computed. Both the M1 and M2 profiles converge on the true profile, and thus at distance $L$ upstream the error caused by assuming an incorrect initial elevation virtually disappears.

The distance required for convergence may be estimated from Bresse's equations (Woodward and Posey, 1941) for bacl water curves. Assuming that flow is steady, uniform, and in a rectangular channel, that the initial depth is either 0.75 or 1.25 times the normal depth, and that the profiles converge where the computed depth is either 0.97 or

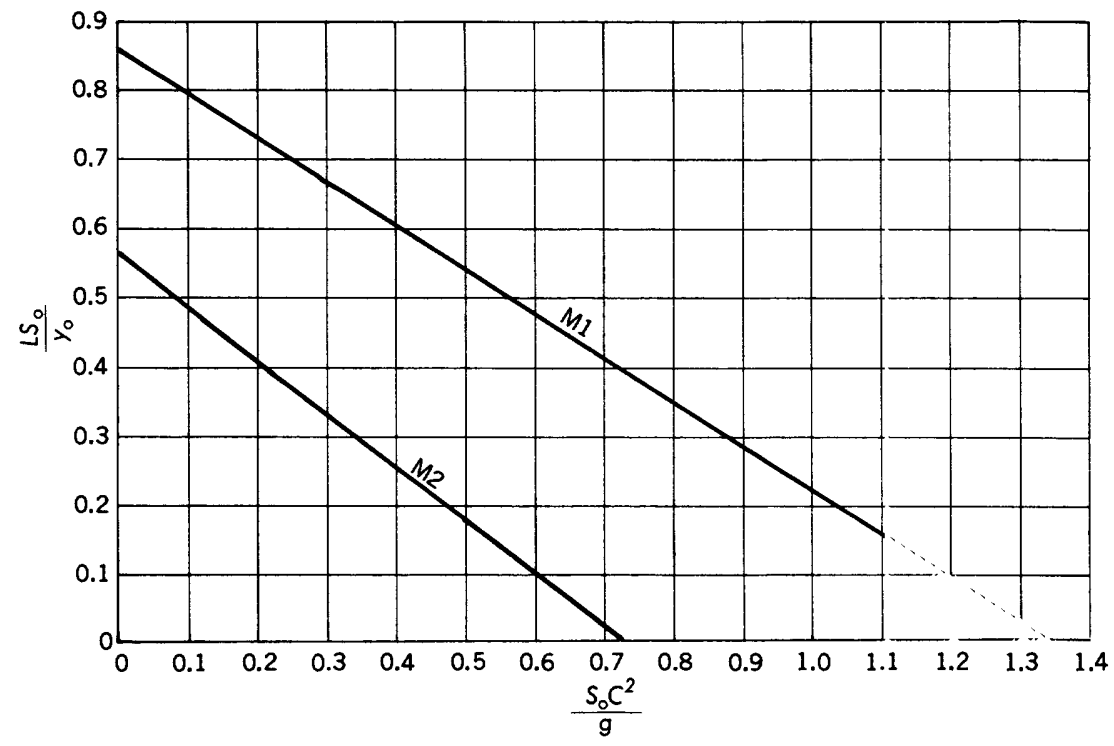

Figure 2.-Equations 2 (M1) and 3 (M2) for determination of c'istance required for convergence. 
1.03 times the normal depth, the required total reach length $L$ may be computed for given values of bed slope, $S_{0}$, normal depth, $y_{0}$ and Chezy roughness coefficient, $C$.

$$
\begin{aligned}
& \frac{L S_{o}}{y_{o}}=0.8598-0.6398 \frac{S_{o} C^{2}}{g}(\mathrm{M} 1 \text { Curve }), \\
& \frac{L S_{o}}{y_{o}}=0.5676-0.7876 \frac{S_{o} C^{2}}{g}(\mathrm{M} 2 \text { Curve }) .
\end{aligned}
$$

For an infinitely wide rectangular channel it can be shown that $S_{0} C^{2} / g=\mathbf{F}^{2}$. Equations 2 and 3 are shown in graphical form in figure 2 ; for any given channel the M2 curve converges in a shorter distance. than the M1 curve. Equations 2 and 3 were used as general guides for determining the length of reaches to be surveyed in the field.

\section{COLLECTION OF FIELD DATA}

A transit-stadia survey of a long reach of stream channel downstream from the gage was made at each study site. The surveys were run using the same basic techniques described by Benson and Dalrymple (1966) for indirect discharge measurements:

1. Gage datum was established by levels throughout the length of the reach.

2. Cross sections of the stream were surveyed at intervals along the reach. Cross sections were located where major breaks in the high-water profile would be expected to occur because of changes in cross-section properties along the channel. Cross sections were spaced at a minimum interval of about one channel width. An average of 9 cross sections were taken.

3. Roughness coefficients were selected in the field for the reach adjacent to each cross section. Cross sections were subdivided where appropriate, and roughness coefficients were selected for each subsection. Roughness coefficients were selected for different depths of flow in each section or subsection where roughness was believed to vary with depth.

4. Color photographs of the channel were taken at points along the reach. These photographs were used in reviewing the values of roughness coefficients selected by the field engineer. Final values of the roughness coefficients were selected before any computations of water-surface profiles were made.

A summary of channel characteristics as determined by fielc surveys at the 28 sites is shown in table 1 . The tabulation shows that the drainage area ranged from 5.18 to 8,550 square miles and that slope ranged from 0.000488 to 0.00992 . The values of slope shown are for the water-surface profile defined at the time of the field survey. 
The top widths and mean depths shown in columns 5 and 6 are for the cross section at the gage. The range in values of Manning's $n$ shown in column 7 represents the range in values selected in the reach for the main channel. Values of Froude number in column 8 are the maximum values computed for the section at the gage. This maximum Froude number varies from 0.17 to 0.98 . The data summary presented in table 1 shows the wide variation in hydraulic conditions found at the study sites.

\section{ESTIMATION OF STAGE-DISCHARGE RELATION AT INITIAL SECTION}

The procedure used in computing water-surface profiles requires an estimate of the stage-discharge relation at the initial section in the reach. In this study all flows were subcritical and the initial section was the one farthest downstream. The following procedure was used to estimate this relation:

1. The conveyance $K$ of the initial section was computed for various water-surface elevations as

$$
K=\frac{1.49 A R^{2 / 3}}{n} \text {. }
$$

2. The slope of the water surface in the lower part of the reach at the time of the survey was determined.

3 . The discharge at various water-surface elevations was then computed as the conveyance times the square root of the slope.

4. The stage-discharge relation was plotted.

Starting elevations at the initial section for a selected discharge were taken from the stage-discharge relation.

\section{COMPUTATION OF WATER-SURFACE PROFILES}

Water-surface profiles for selected discharges were computed for each reach using the data obtained in the field survey to define the variables in equation 1. Solutions of equation 1 from section to section were obtained by an electronic computer. The following procedure was used at each station:

1. A discharge was selected.

2. The water-surface elevation at the initial section for the selected discharge was determined from the estimated stege-discharge relation at the initial section.

3. The water-surface profile for the selected discharge from the initial section to the gage was computed.

4. The procedure was repeated for successively higher discharges.

5. Convergence in the reach was tested for several of tha discharges by assuming starting elevations at the initial section that were 


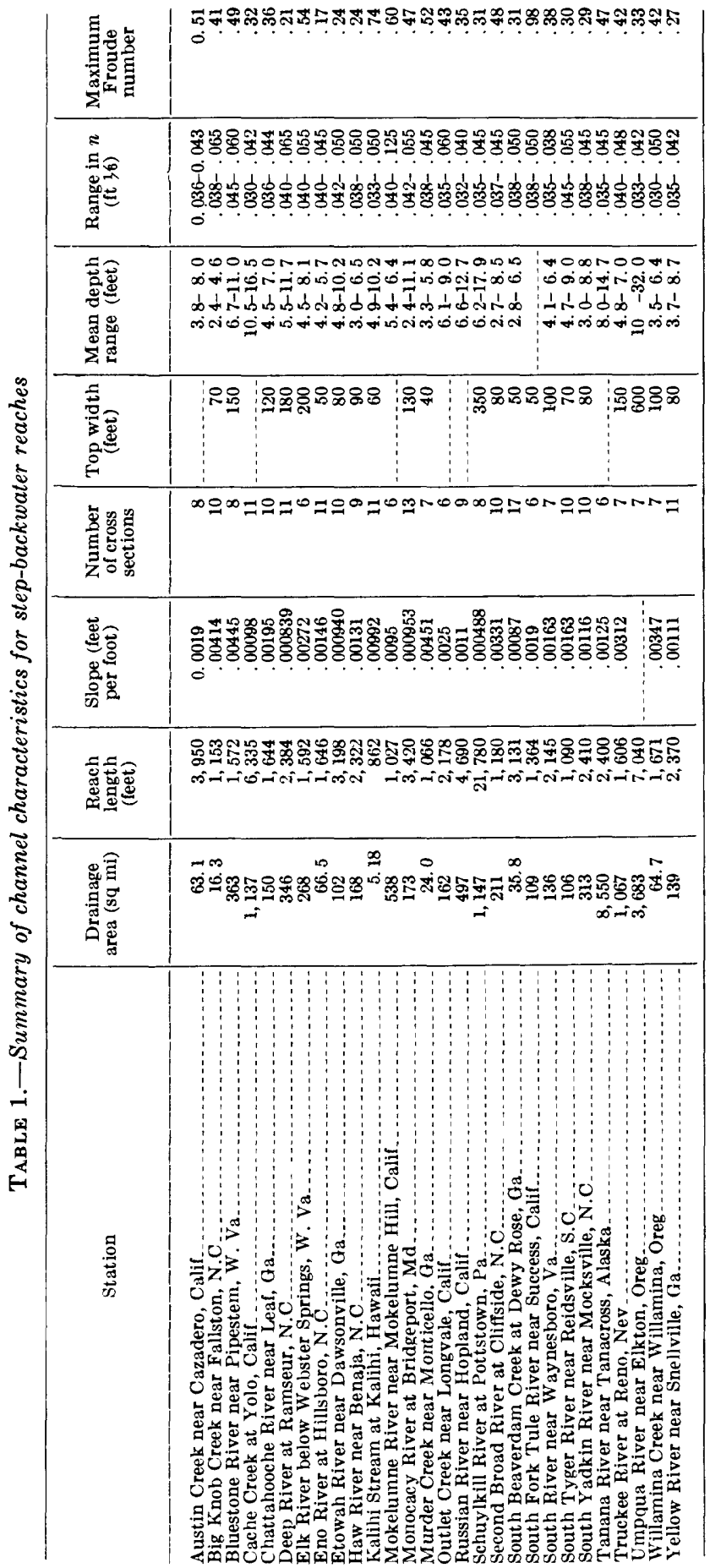


higher and lower than the elevation indicated by the stage-discharge relation-for example, computations for a discharge of $400 \mathrm{cfs}$ (cubic feet per second) at the Fallston, N.C. site were carried upstream from the initial section at beginning elevations of $2,2.6,3.5$, and 5 feet. As shown in figure 3 , all four profiles converge to a stage of 8 feet at the gage.

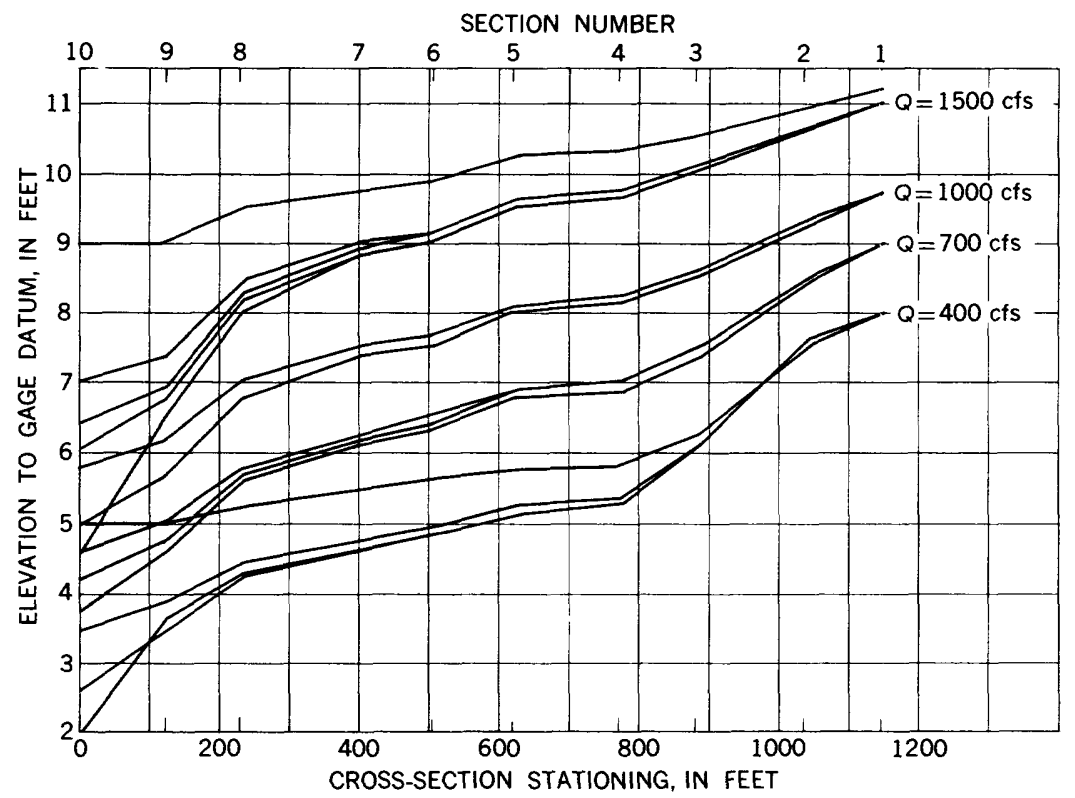

Figure 3.-Water-surface profile convergence pattern, Big Knob Creek near Fallston, N.C.

\section{COMPUTATED STAGE-DISCHARGE RELATION AT GAGE}

The discharges and the corresponding stages at the gage determined from the backwater profiles were plotted to define the computed stage-discharge relation at the gage. Definition of these curves was purposely limited to the range from medium flow to the highest flow measured at the gage by the current-meter method. Section controls usually exist at lower flow and the assumption of uniform flow in the reach becomes less valid.

\section{COMPARISON OF COMPUTED AND MEASURED STAGE- DISCHARGE RELATIONS}

The state-discharge relation points computed from the stepbackwater analysis are compared with stage-discharze relations (rating curves) defined by current-meter measurements in figures 4-31. In general, the agreement between the measured and the computed data is remarkably good. A summary of the comparison is shown in figure 32. The standard deviation of the departures of the computed values is +19 and -16 percent; this deviation indicates 
that there is little overall bias in the method. There is a tendency for closer agreement as the discharge increases at a given station and as the flow in the channel becomes more uniform. The primary source of error is probably in the selection of roughness coefficients

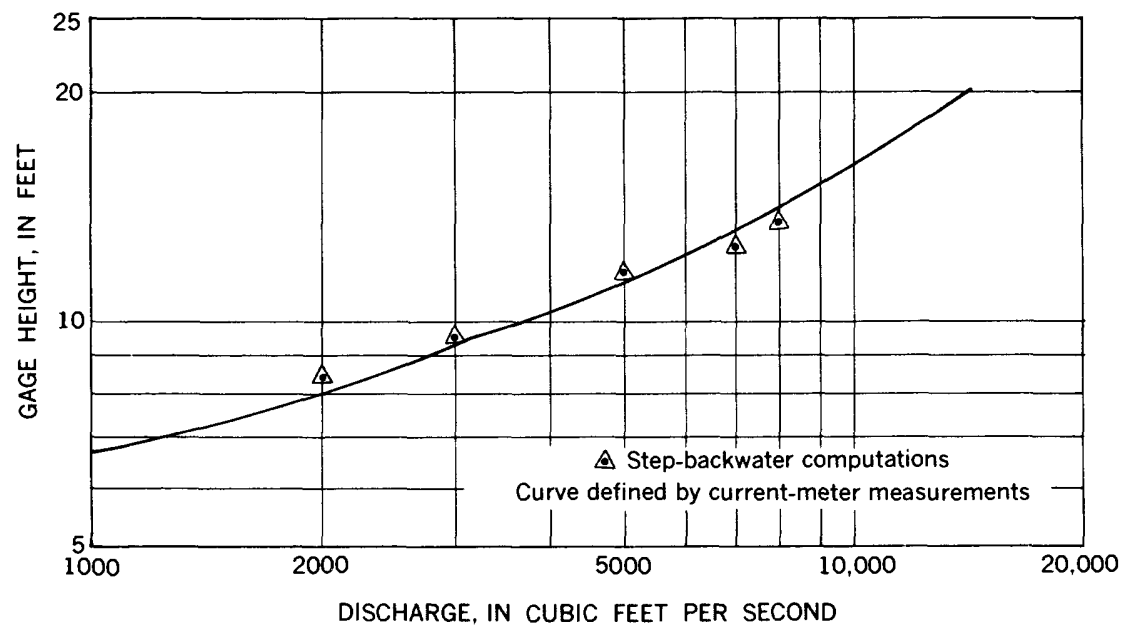

Figure 4.-Rating curve for Austin Creek near Cazadero, Calif.

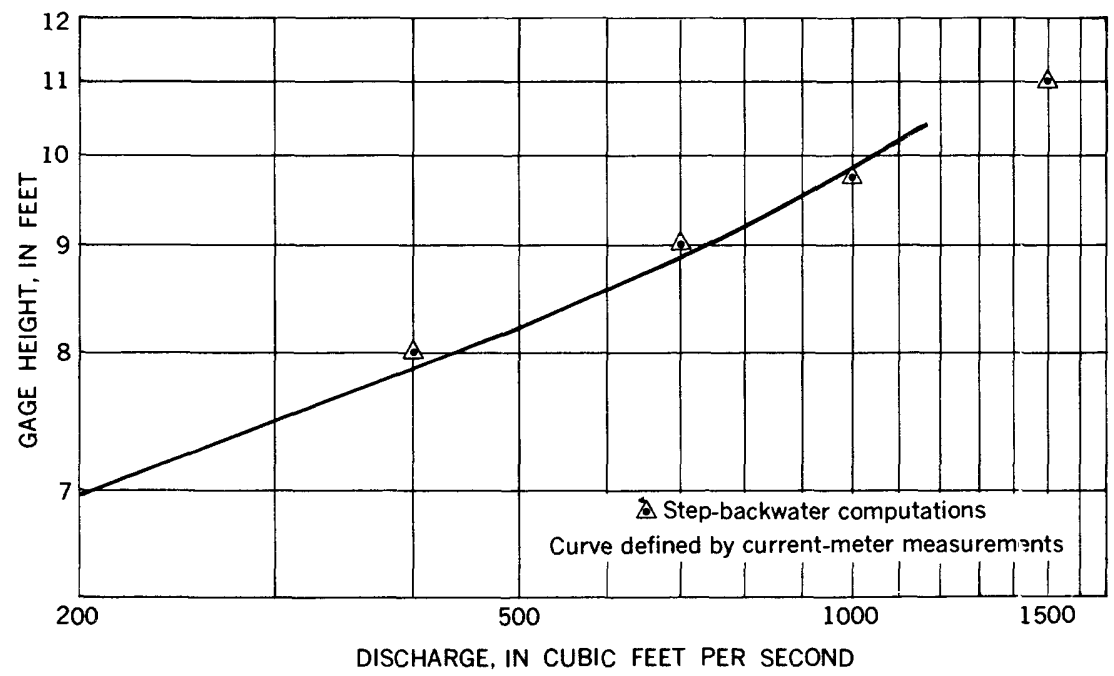

Figure 5.- Rating curve for Big Knob Creek near Fallston, N.C. 


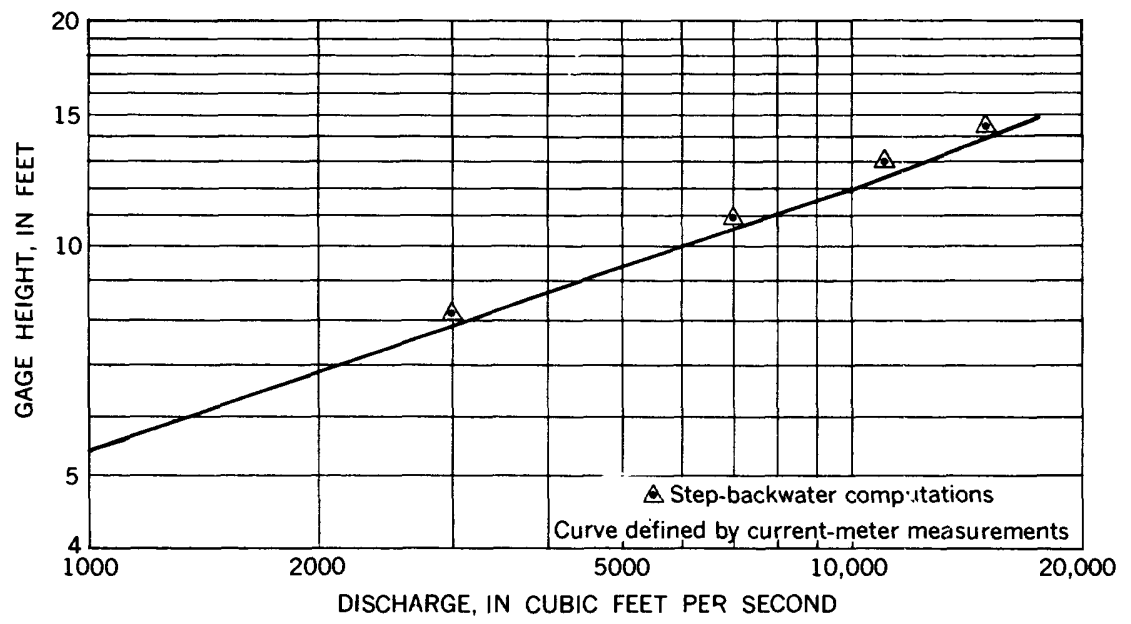

Figdre 6.-Rating curve for Bluestone River near Pipestem, W. Va.

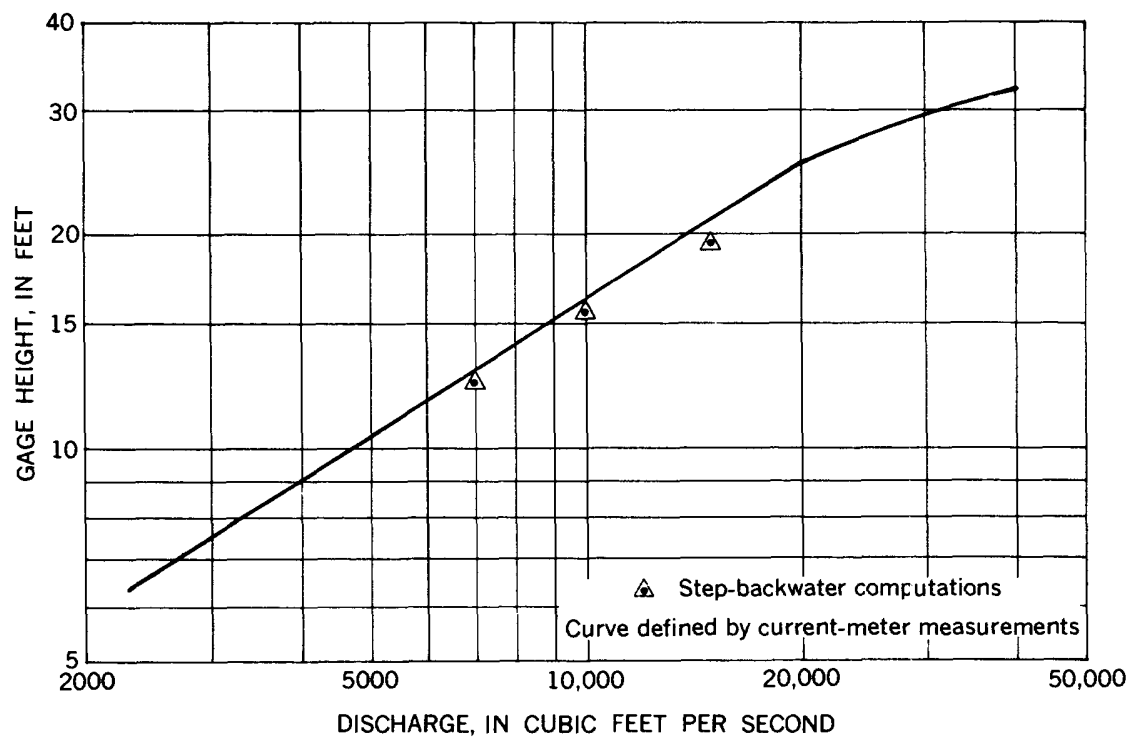

Figure 7.- Rating curve for Cache Creek at Yolo, Calif. 


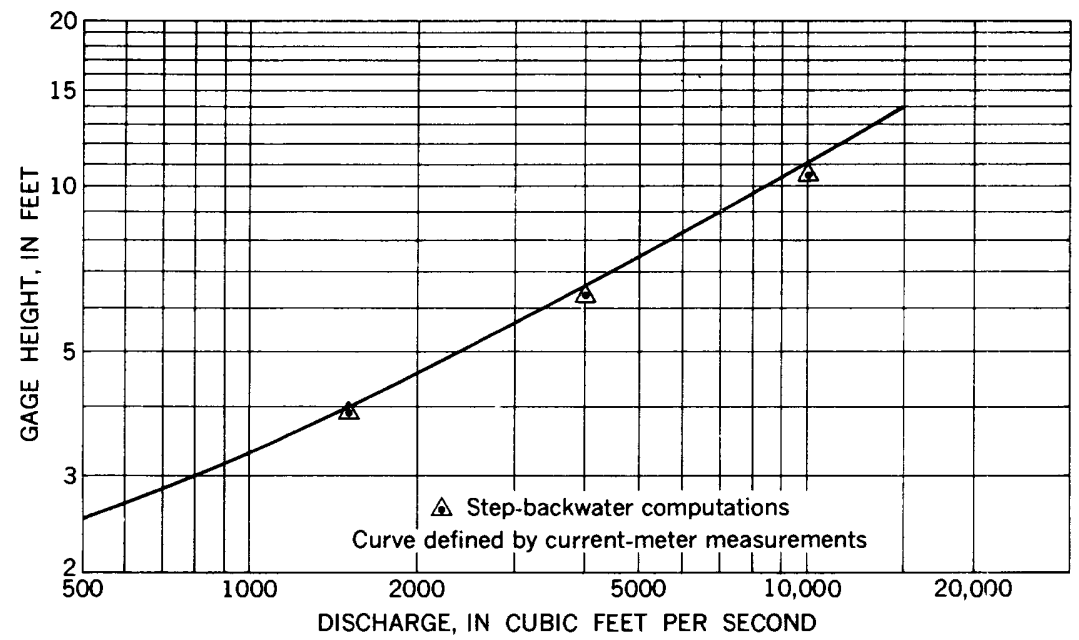

Fraure 8.-Rating curve for Chattahoochee River near Leaf, Ga.

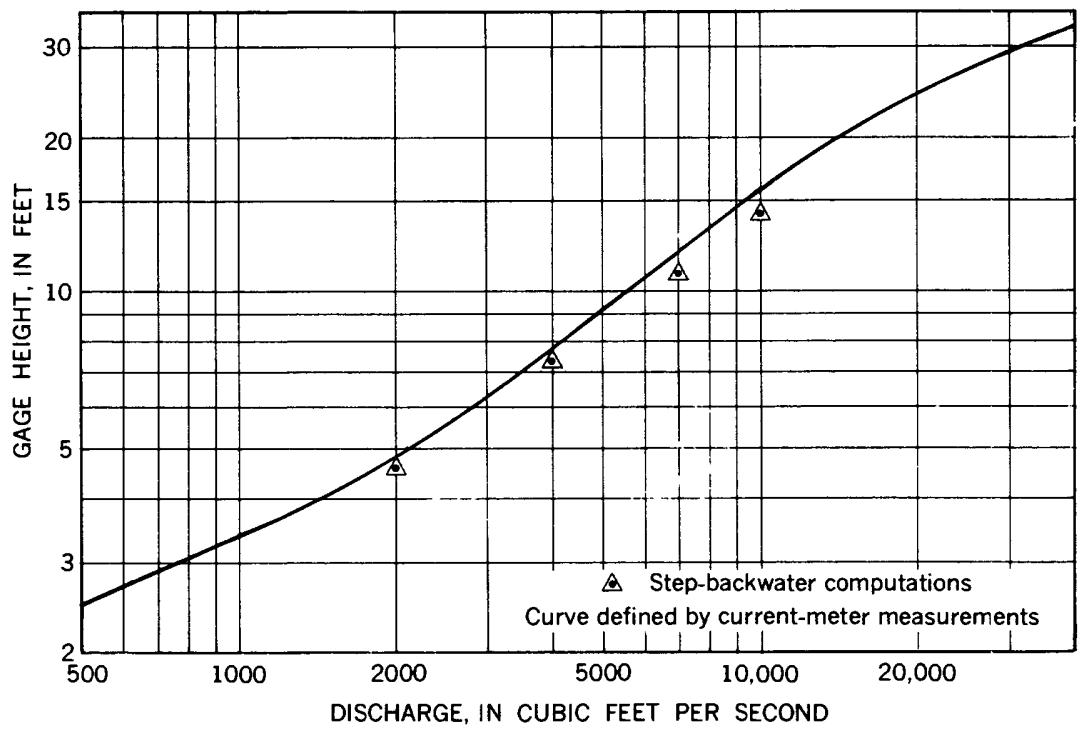

Figure 9.-Rating curve for Deep River at Ramseur, N.C. 


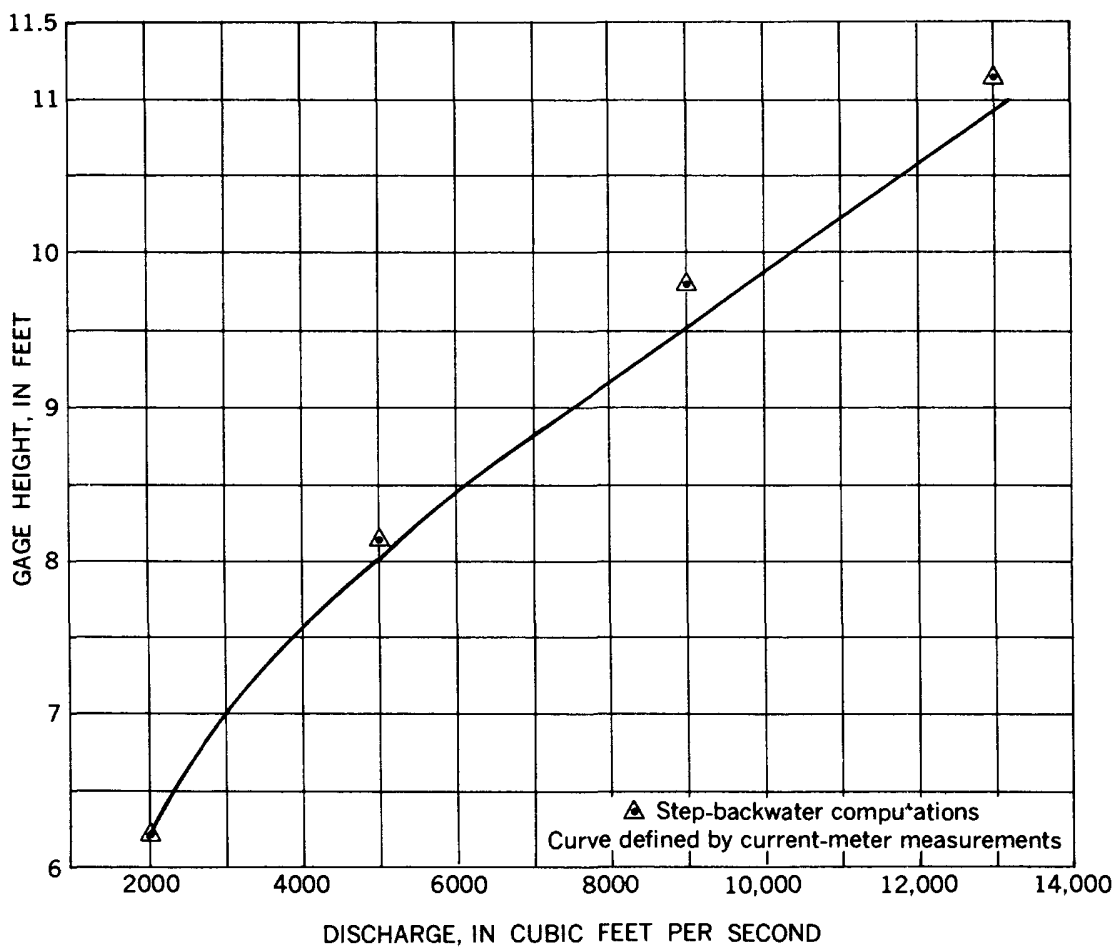

Figure 10.- Rating curve for Elk River below Webster Springs, W. Va. 


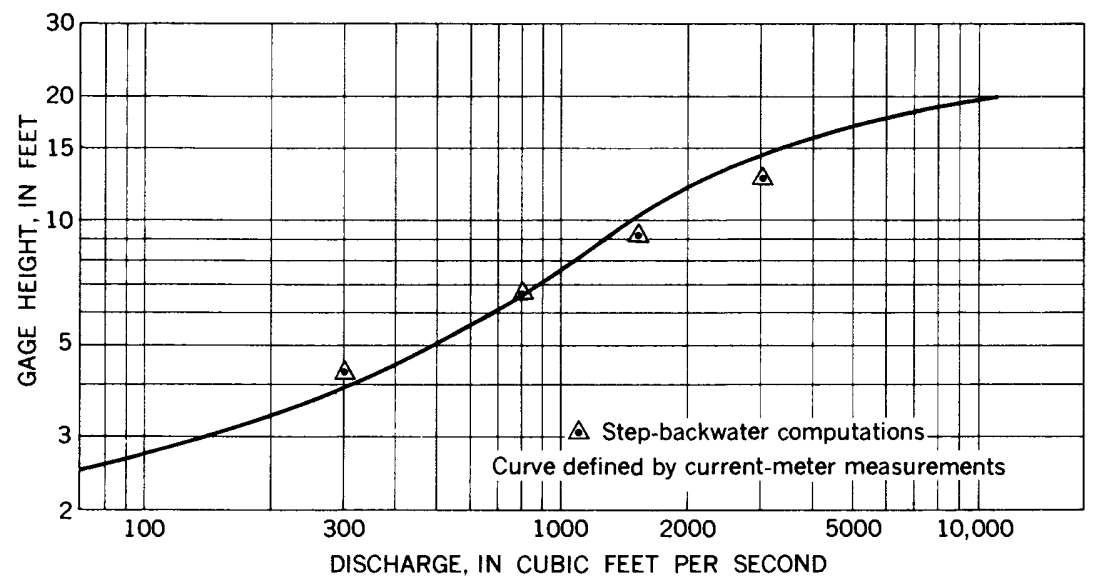

Figdre 11.-Rating curve for Eno River at Hillsboro, N.C.

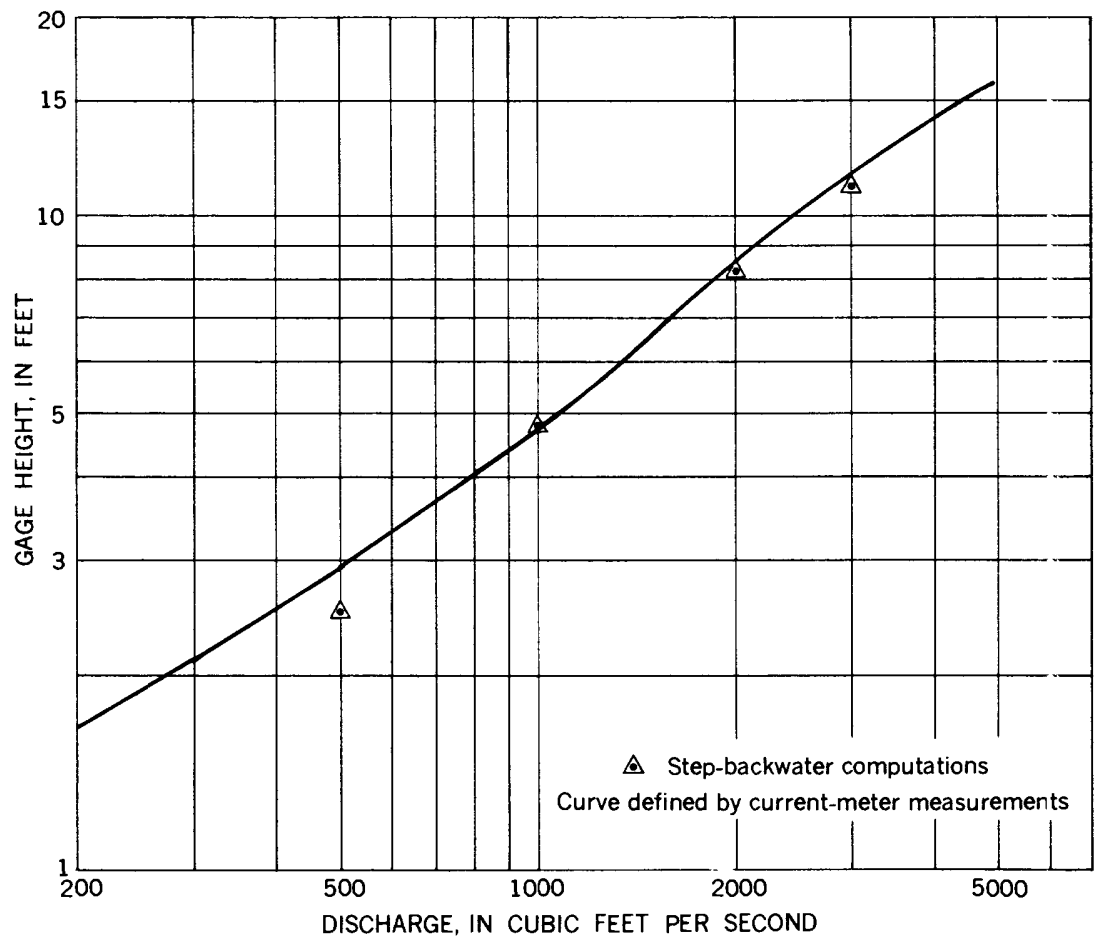

Figure 12.-Rating curve for Etowah River near Dawsonville, Ga. 


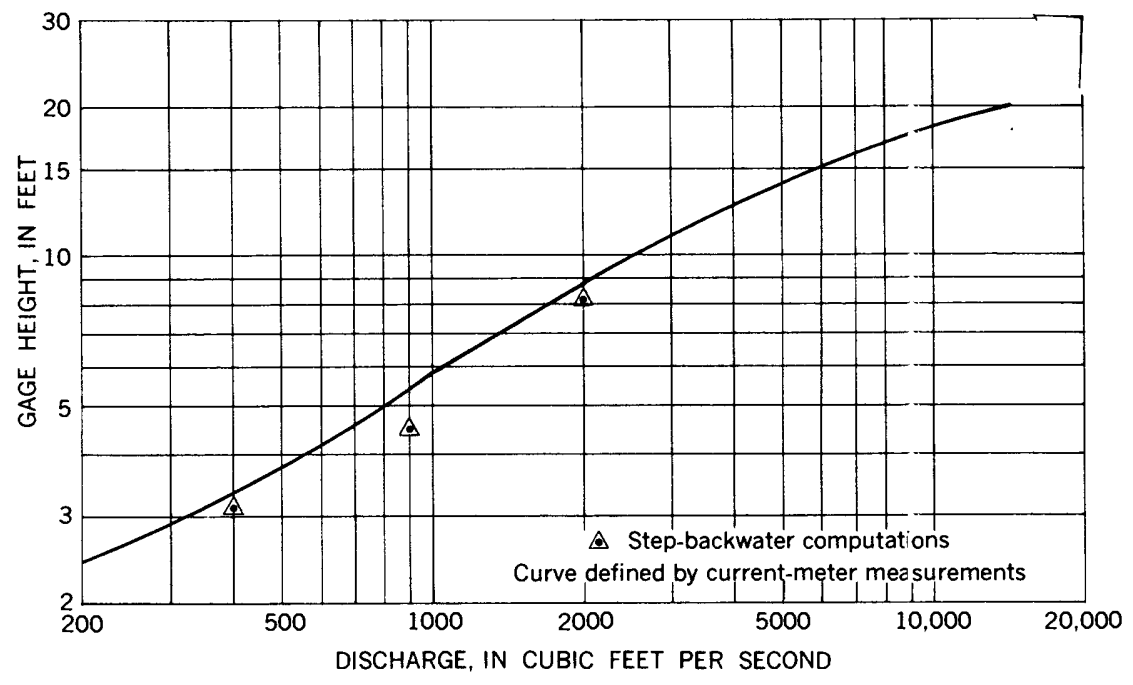

Figure 13.-Rating curve for Haw River near Benaja, N.C.

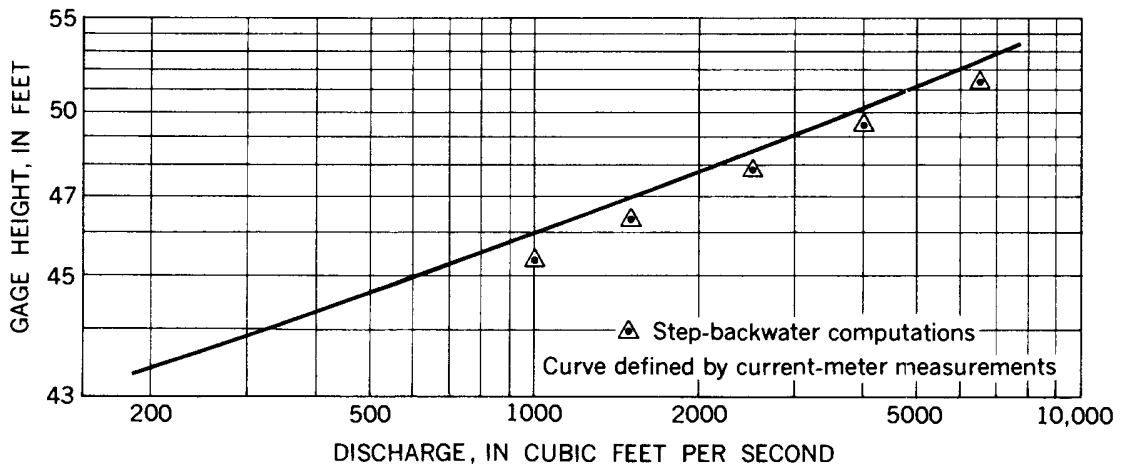

FIGURe 14.-Rating curve for Kalihi Stream at Kalihi, Hawaii. 


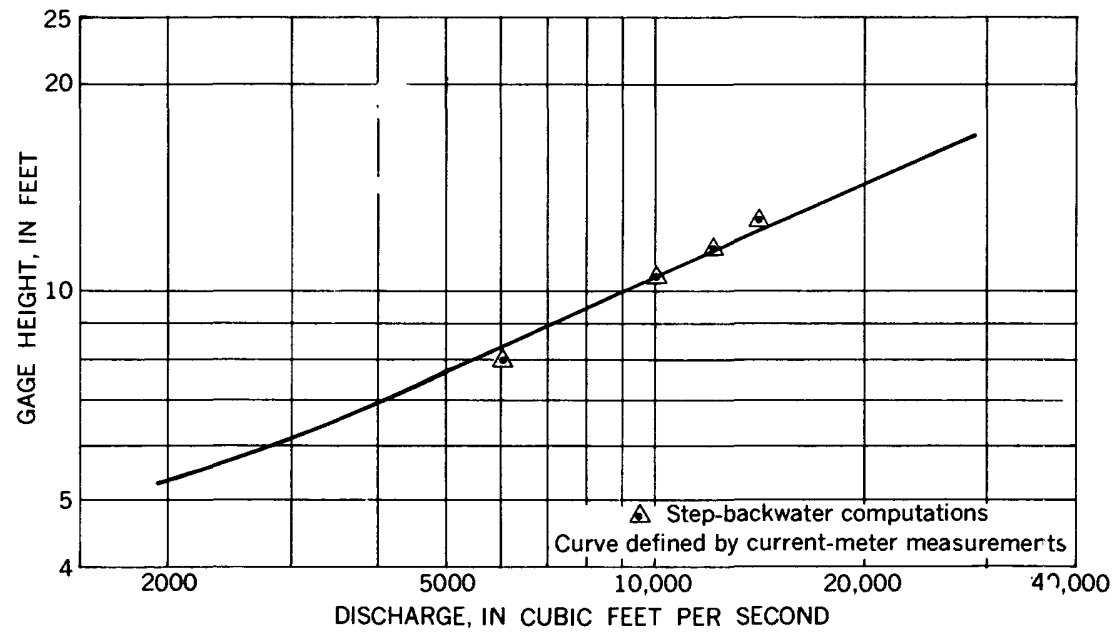

Figure 15.- Rating curve for Mokelumne River near Mokelumne Hill, Calif.

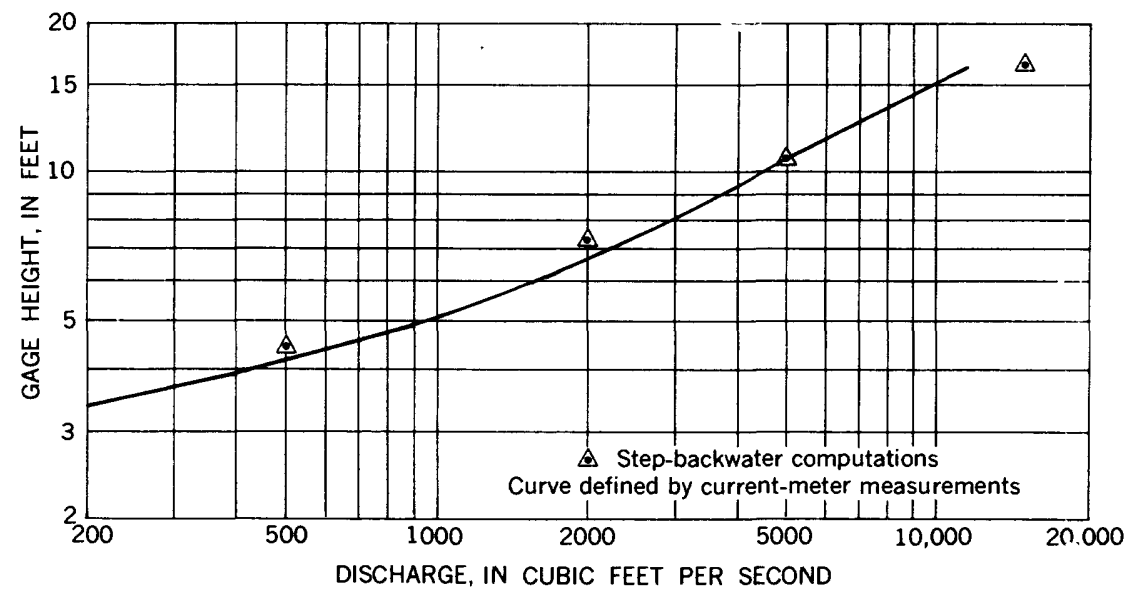

Figure 16.- Rating curve for Monocacy River at Bridgeport, Md. 


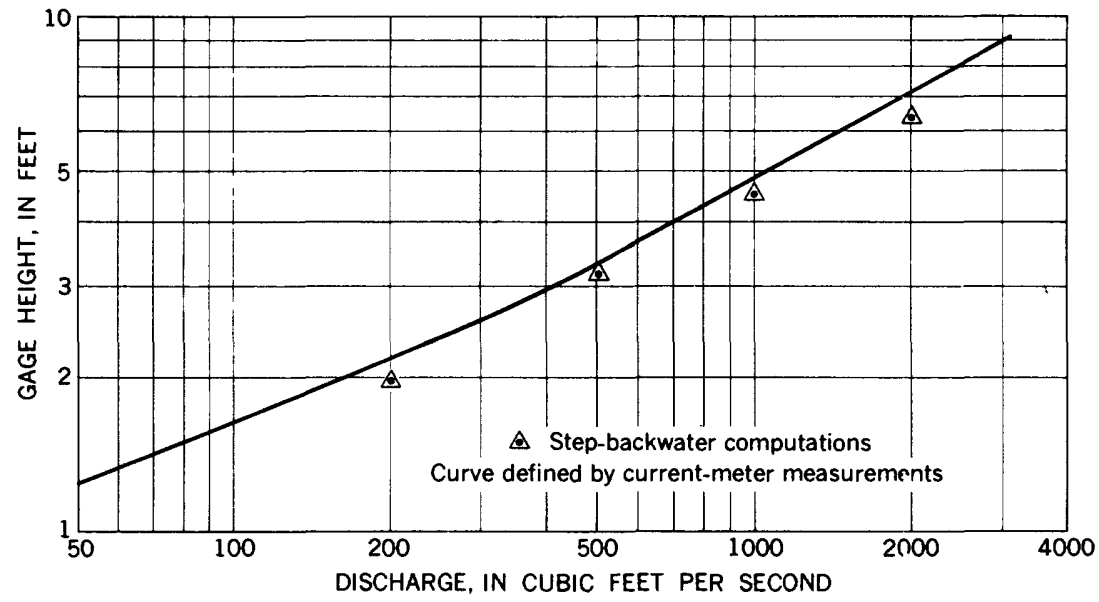

Figure 17.-Rating curve for Murder Creek near Montic sllo, Ga.

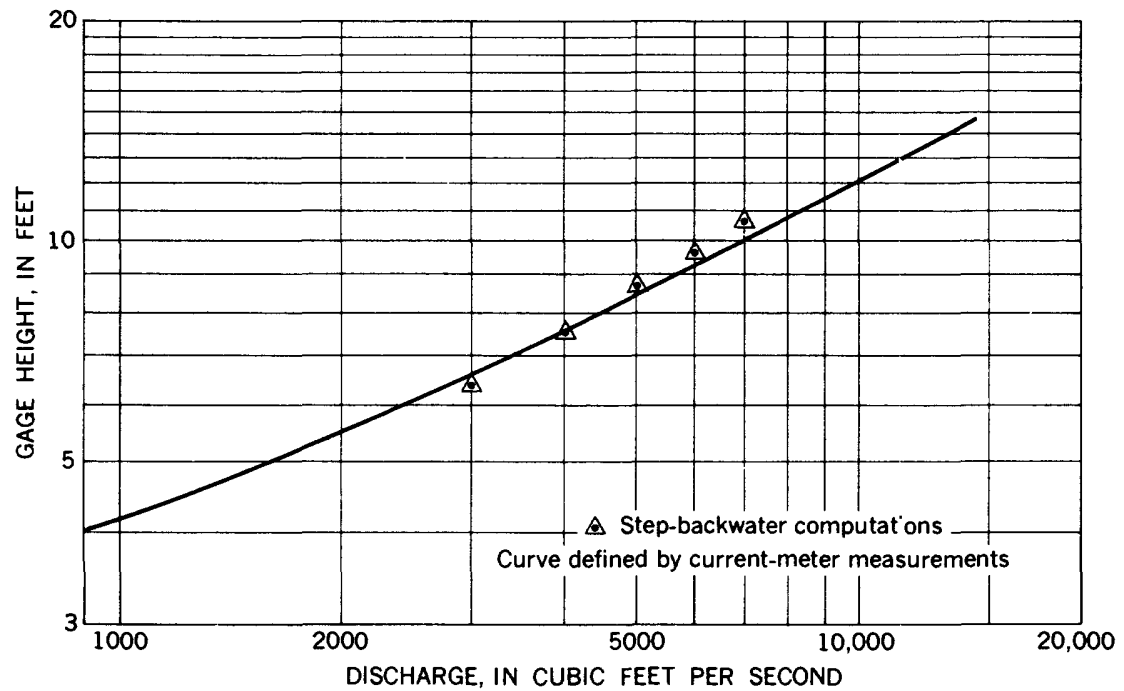

Figure 18.-Rating curve for Outlet Creek near Longvalo, Calif. 


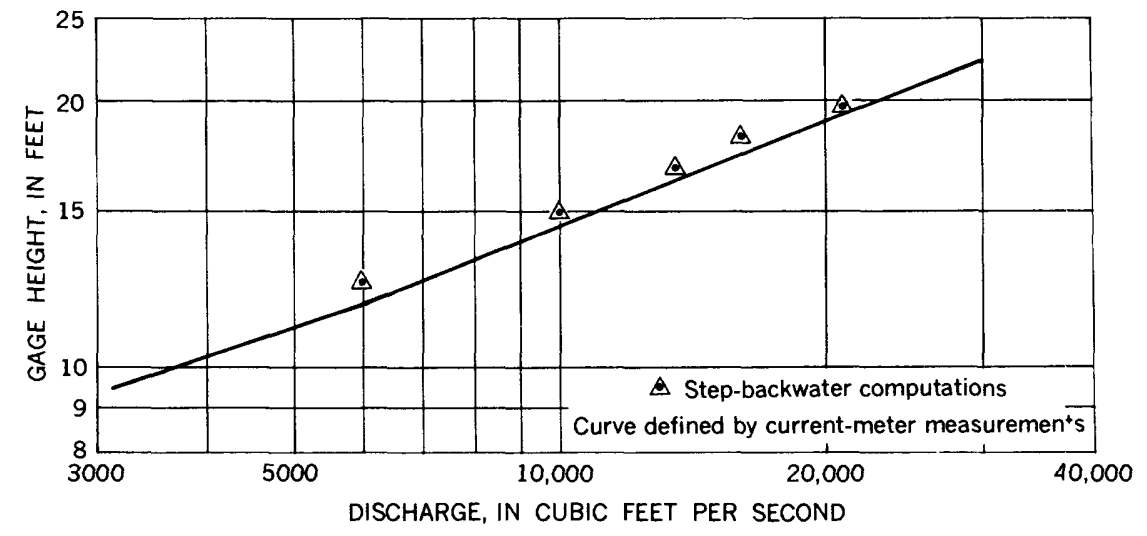

Figure 19.-Rating curve for Russian River near Hopland, Calif.

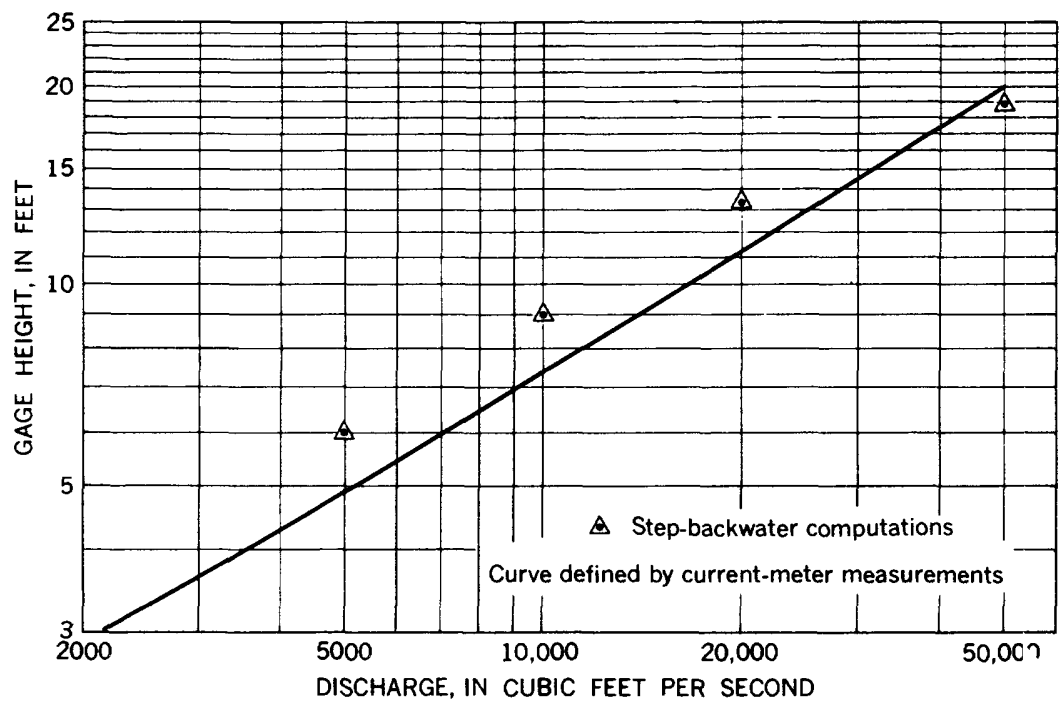

Figure 20.-Rating curve for Schuylkill River at Pottstown, Pa. 


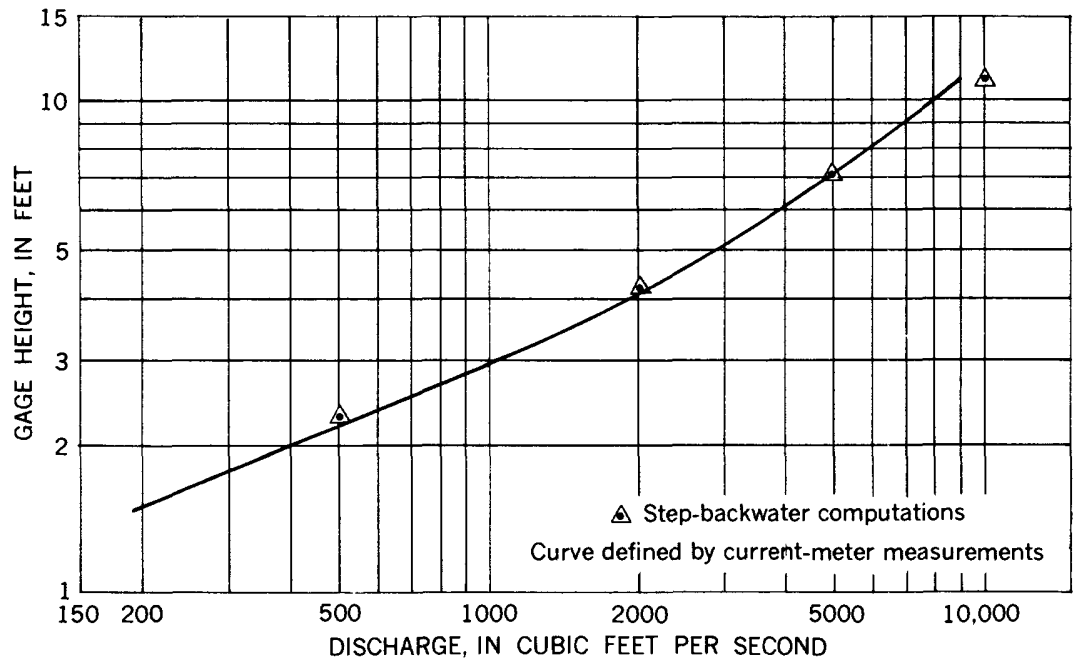

Figure 21.--Rating curve for Second Broad River at Cliffside, N.C.

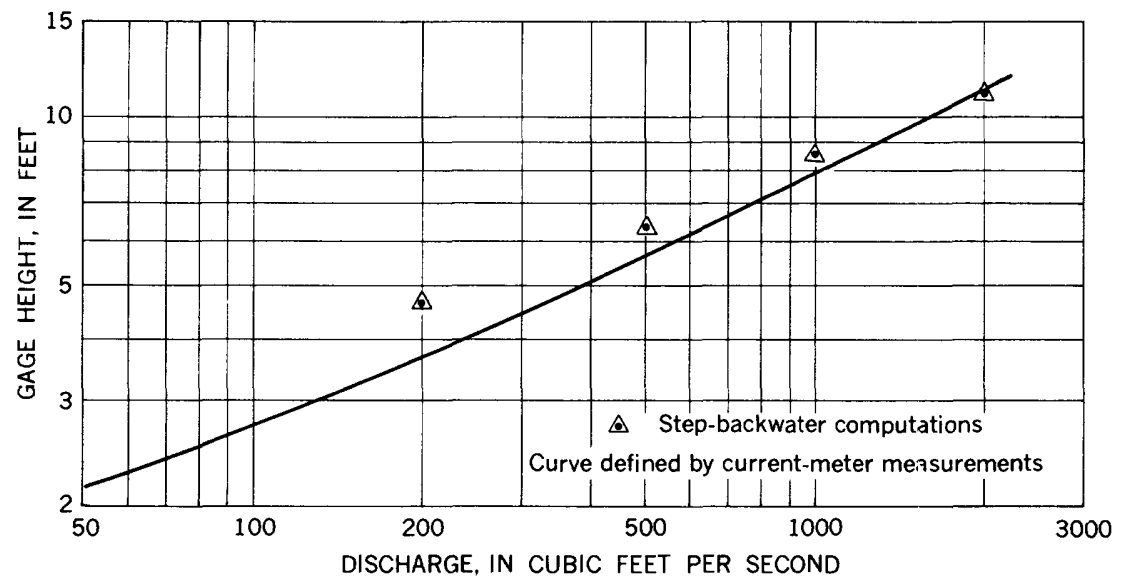

FIGURE 22.-Rating curve for South Beaverdam Creek at Devry Rose, Ga. 


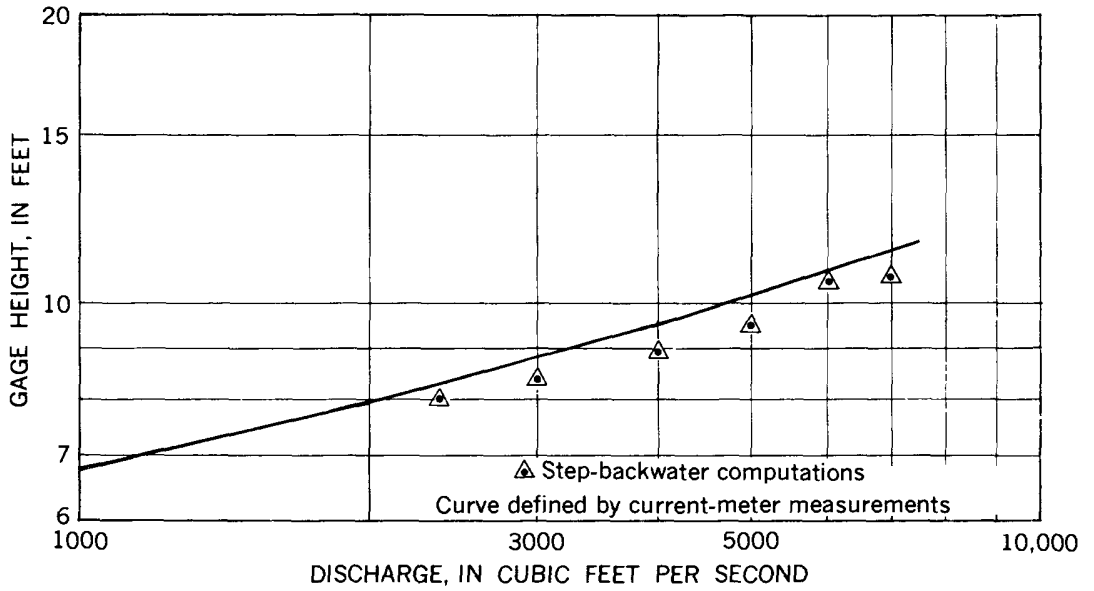

Figure 23.-Rating curve for South Fork Tule River near Success, Calif.

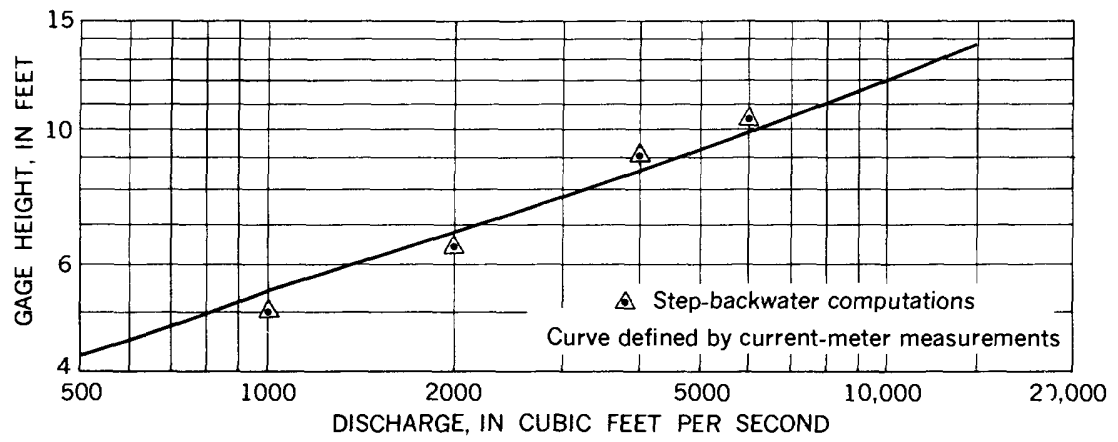

Figure 24.- Rating curve for South River near Waynesboro, Va.

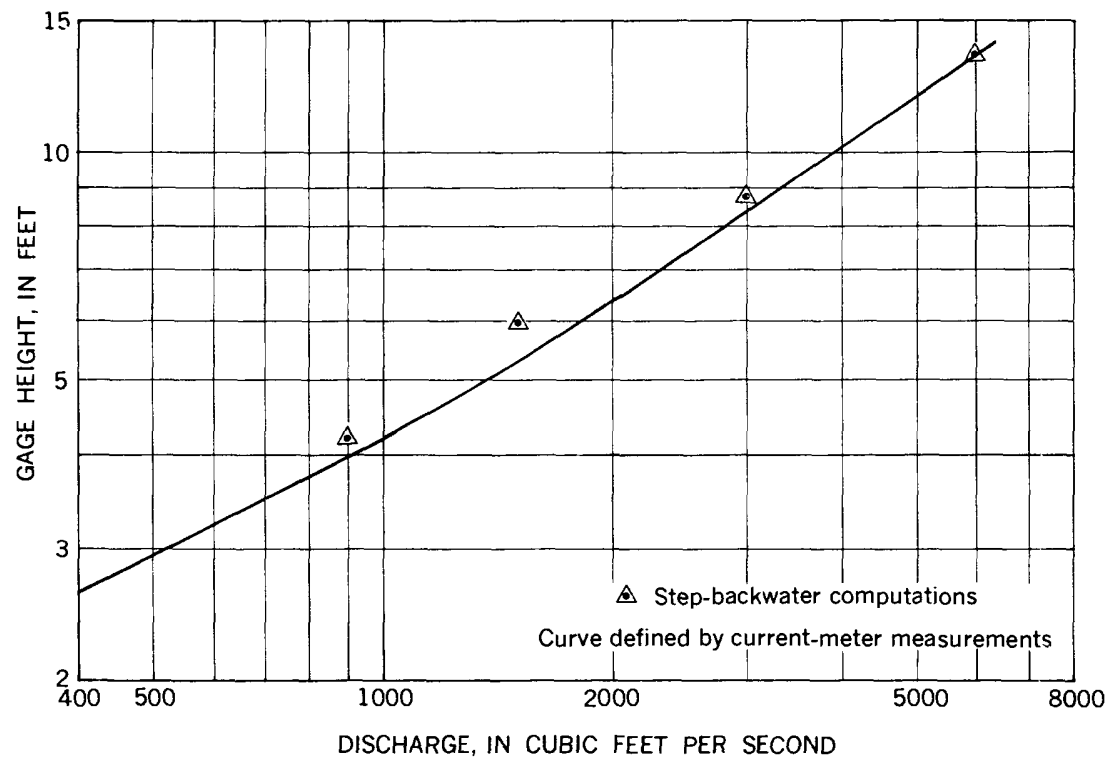

Figure 25.-Rating curve for South Tyger River near Reidsville, S.C. 


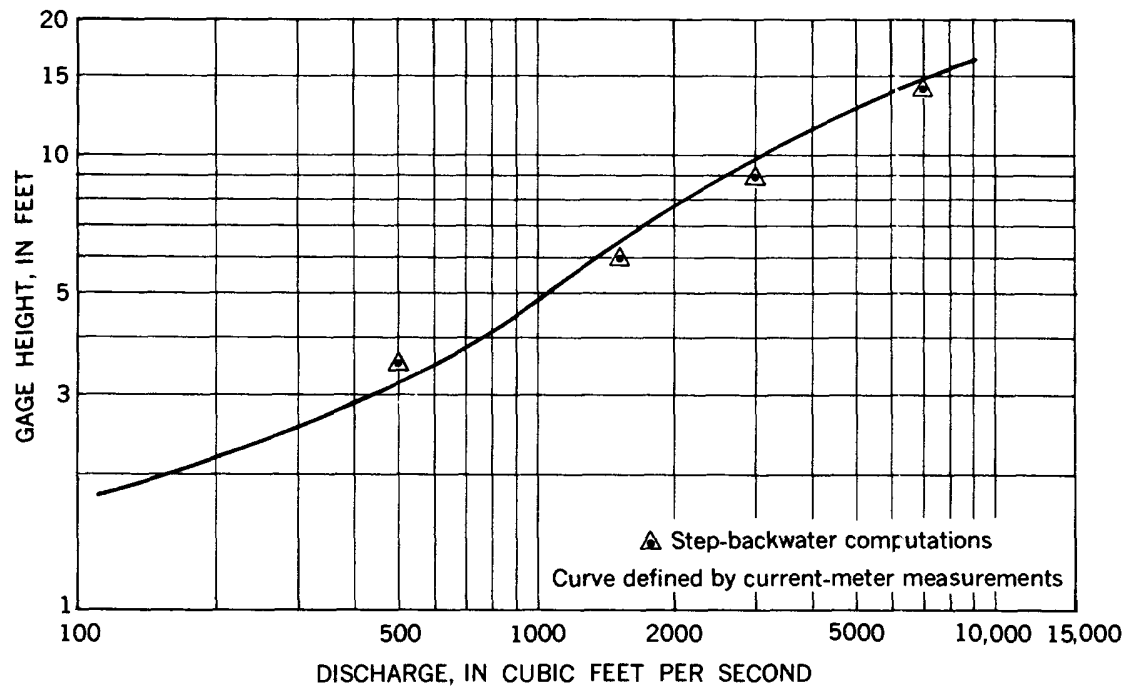

Figure 26.-Rating curve for South Yadkin River near Mocksville, N.C.

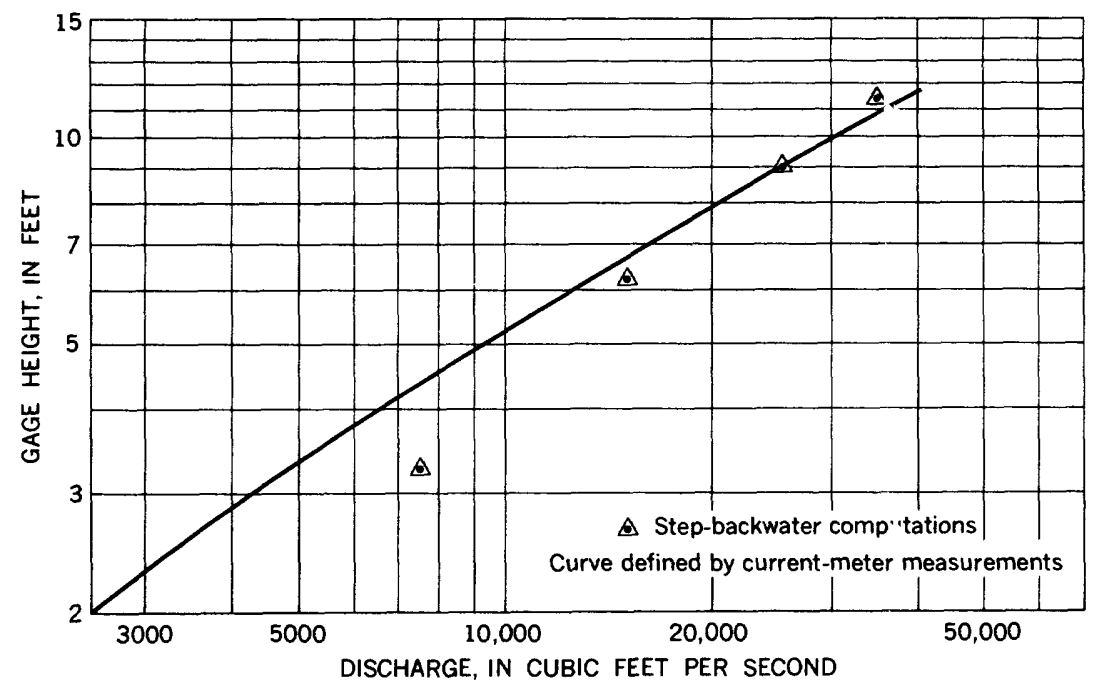

Figure 27.-Rating curve for Tanana River near Tanacrors, Alaska. 


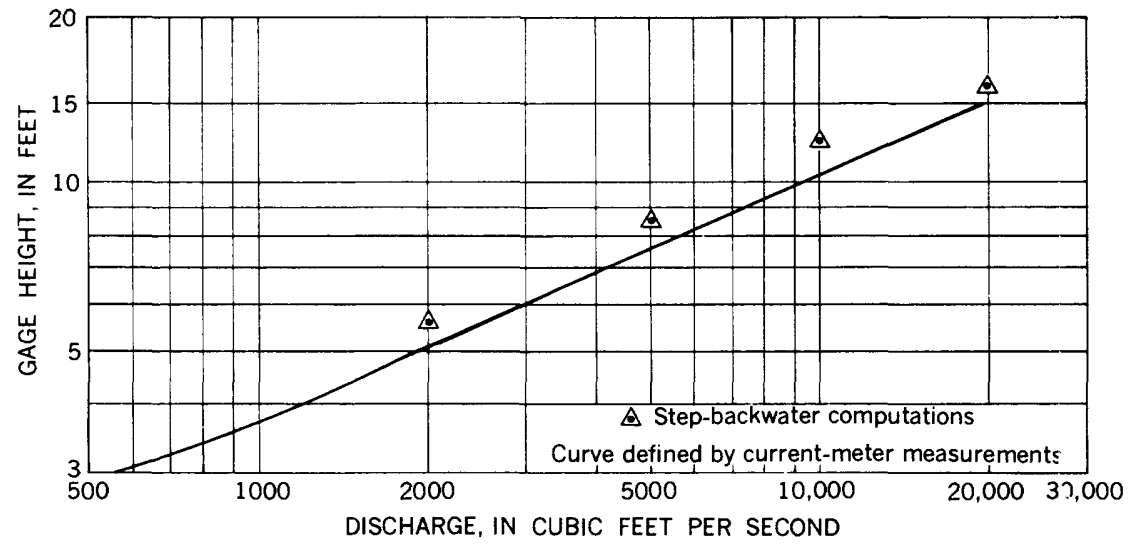

Figure 28.- Rating curve for Truckee River at Reno, Nev.

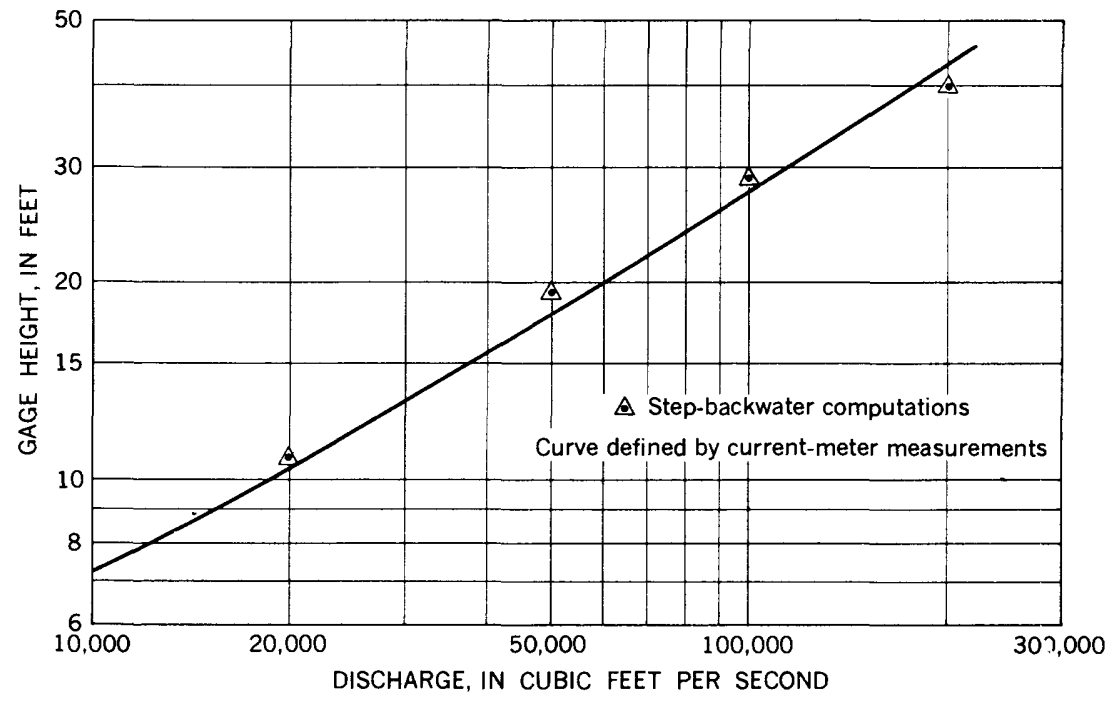

Figure 29.-Rating curve for Umpqua River near Elkton, Oreg. 


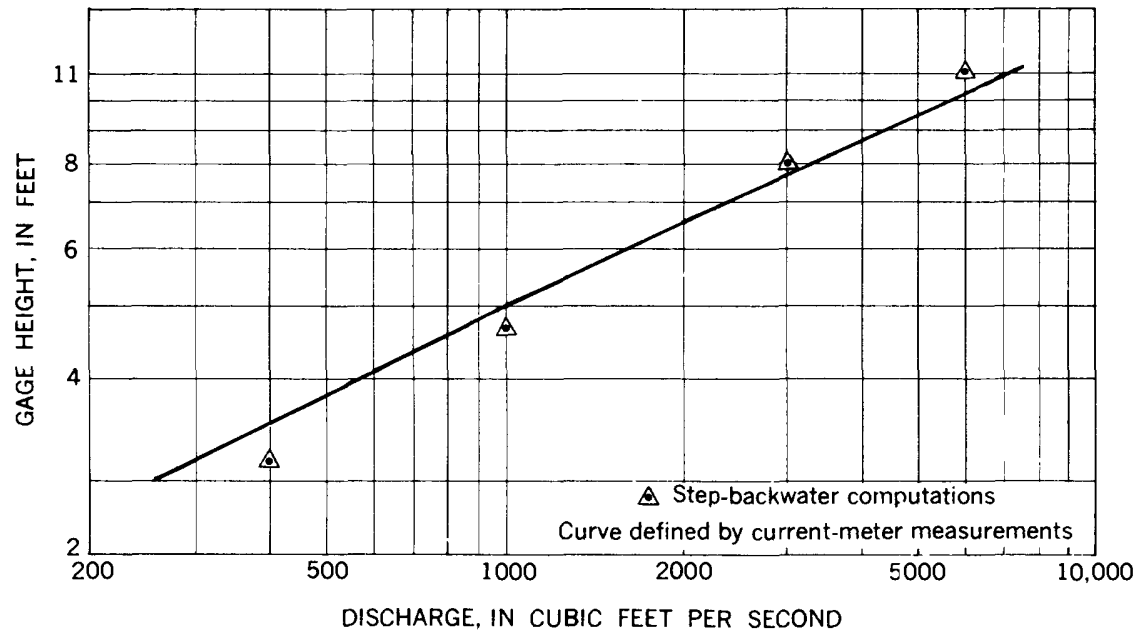

Figure 30.--Rating curve for Willamina Creek near Willamina, Oreg.

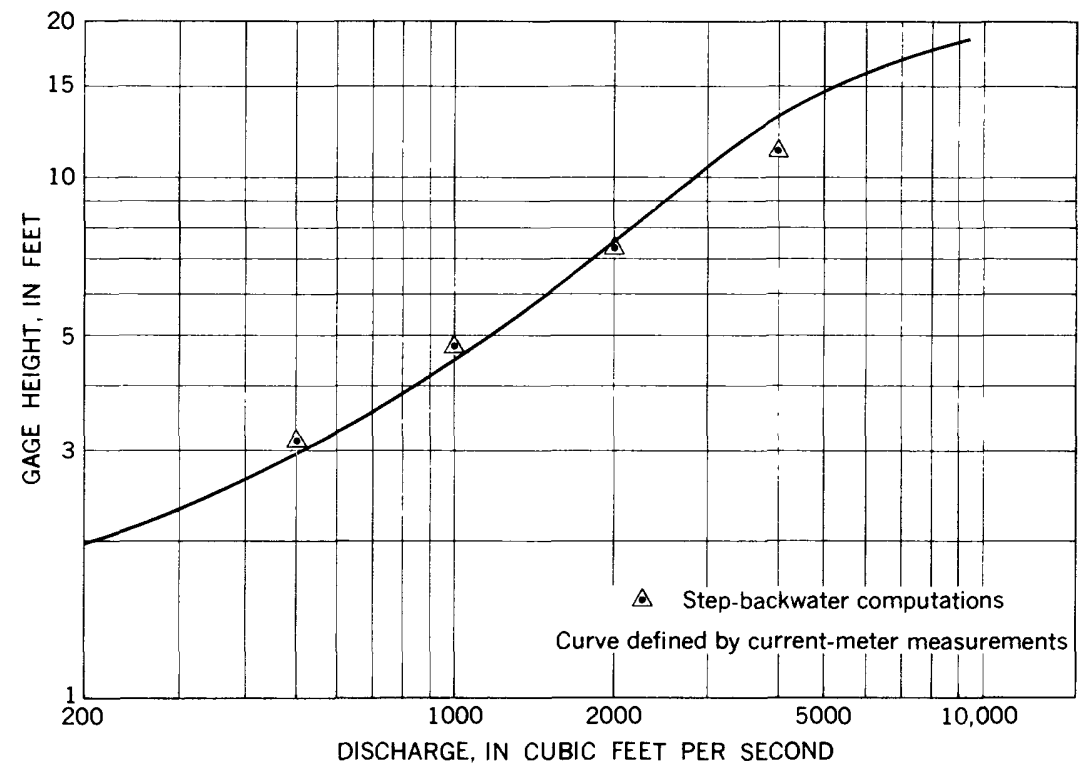

FIGURE 31.-Rating curve for Yellow River near Snellville, Ga. 


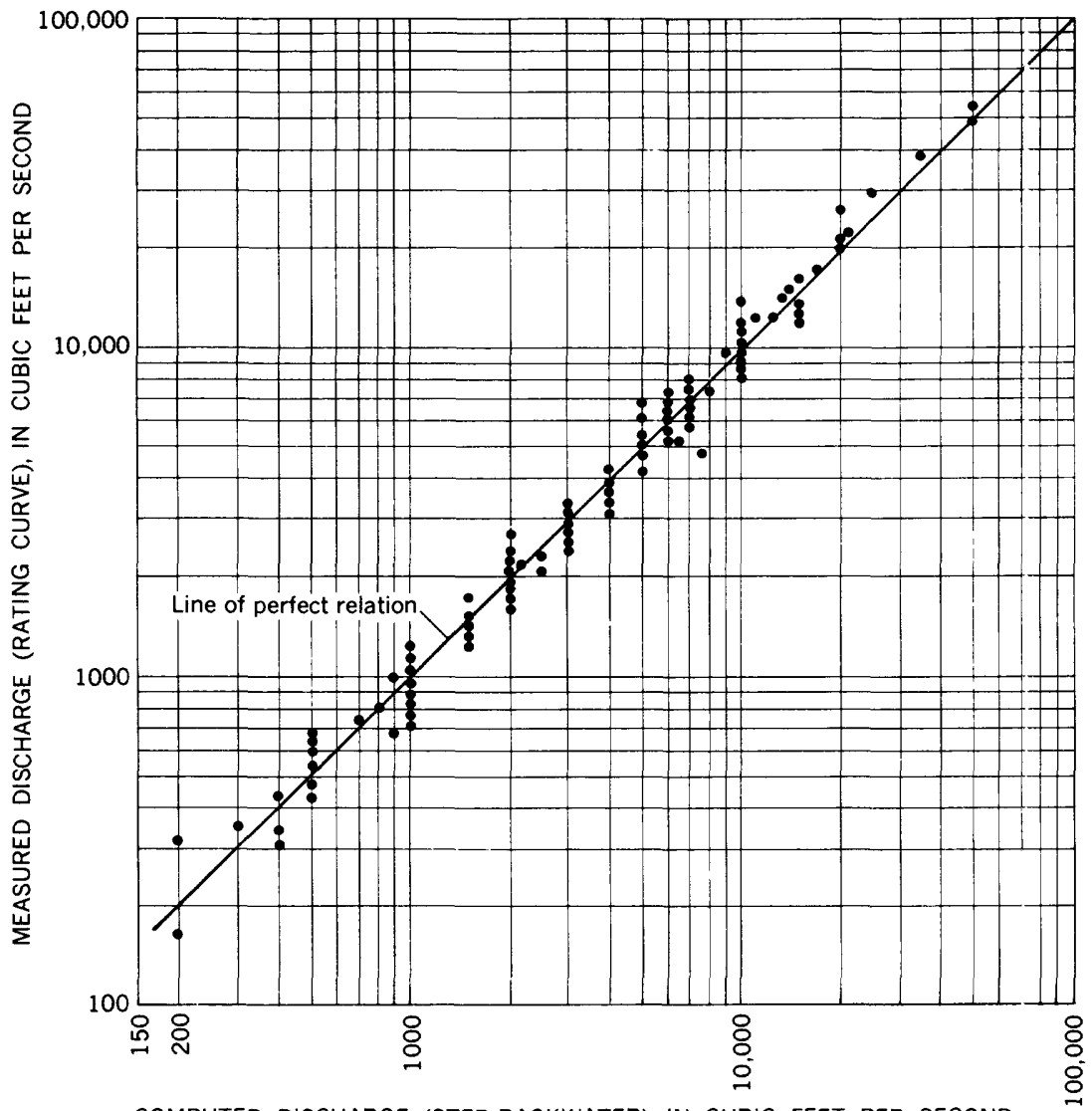

COMPUTED DISCHARGE (STEP-BACKWATER), IN CUBIC FEET PER SECOND

Figure 32.-Computed discharge compared with measured discharge.

\section{CONCLUSIONS}

1. Stage-discharge relations established by step-backwater anclysis closely approximate the corresponding stage-discharge relations defined by current-meter measurements at the 28 sites used in this investigation. The standard deviation of the comruted discharges, +19 and -16 percent, indicates little overall bias in the method.

2. Satisfactory stage-discharge relations can be established on any stream regardless of size, slope, and roughness provided definition of channel geometry is possible through an adequate reach length.

3. The step-backwater method of establishing stage-discharge relations can be very useful in the definition of the high-stage part of the rating curves at sites where current-meter measurements are not obtained. 


\section{REFEREN CES}

Benson, M. A., and Dalrymple, Tate, 1966, General field and off ce procedures for indirect discharge measurements: U.S. Geol. Survey Techniques of Water Resources Inv., book 3, chap. 3 (in press).

Bodhaine, G. L., 1966, Measurement of peak discharge at culverts by indirect methods: U.S. Geol. Survey Techniques of Water Resources Inv., book 3, chap. 5 (in press).

Dalrymple, Tate, and Benson, M.A., 1966, Measurement of peak discharge by the slope-area method: U.S. Geol. Survey Techniques of Wrter Resources Inv., book 3, chap. 4 (in press).

Hulsing, Harry, 1956, Measurement of peak discharge at dars by indirect methods: U.S. Geol. Survey Techniques of Water Resources Inv., book 3, chap. 7 (in prass).

Matthai, H. F., 1966, Measurement of peak discharge at width contractions by indirect methods: U.S. Geol. Survey Techniques of Water Resources Inv., book 3, chap. 6 (in press).

Woodward, S. M., and Posey, C. J., 1941, Steady flow in open channels: New York, John Wiley and Sons, Inc., p. 63-74. 